\title{
ECOLOGIC PERFORMANCE AND SUSTAINABILITY EVALUATION OF A TURBOJET ENGINE UNDER ON-DESIGN CONDITIONS
}

\author{
Yasin ŞÖHRET (D) * \\ Department of Airframe and Powerplant Maintenance, Süleyman Demirel University, Isparta, Turkey
}

Received 19 August 2018; accepted 01 October 2018

\begin{abstract}
Interest in air transportation in the last decade has seen aviation fleet growth and a rise in the energy consumption of aircraft. In accordance with the latest data, the air transportation sector consumes $7.5 \%$ of total oil consumption worldwide. This high share by air transportation forces designers and researchers to develop more efficient propulsion systems by considering the constant rise in energy costs. In the current paper, an exergy based sustainability assessment of a turbojet engine under design point conditions is presented while two novel ecological performance indicators, namely the ecological objective function and ecological coefficient of performance, are introduced for the turbojet engine. These ecological performance indicators can be considered useful for improving the efficiency of any turbojet engine. As a result of an exemplifying analysis, the exergy efficiency, exergy sustainability index, ecological objective function and ecological coefficient of performance have been calculated to be $50.13 \%, 0.503,68.294 \mathrm{~kW}$ and 1.005 , respectively. In the light of the results, the author concludes that the exergy destruction rate of the turbojet engine should be minimized to improve the sustainability index and ecological coefficient of performance, while increasing or maintaining a constant thrust of the examined turbojet engine.
\end{abstract}

Keywords: aviation, ECOP, exergy, propulsion, sustainability, thermodynamics.

\section{Introduction}

With population growth increasing worldwide, energy demand is a challenge for engineers at the design stage to achieve more efficient and more sustainable devices. Energy consuming or generating devices, namely thermal systems, need more attention for a more sustainable, clean, and environmentally friendly design in this manner (Dincer \& Acar, 2017; Cash, 2017; Alva, Lin, \& Fang, 2018). According to the latest report of the International Energy Agency (2017), the air transportation sector accounts for $7.5 \%$ of total oil consumption worldwide, whereas industrial plants consume $8.0 \%$. From this point of view, the oil consumption of air transportation, particularly by aircraft fleets, is as high as that of industrial facilities. Therefore, improvement in aircraft design and achieving more sustainable air transportation are as crucial as energy savings and green projects in industrial plants.

The main part of an aircraft utilizing energy is the propulsion system, where the energy of oil changes from chemical to thermal, followed by mechanical power, and, finally, thrust force and electricity. Therefore, it is important to focus on the propulsion system design to improve efficiency and reduce energy consumption. In many previous studies (Bejan \& Siems, 2001; Rosen \& Etele, 2004; Riggins, Taylor, \& Moorhouse, 2006; Riggins, Moorhouse \& Camberos, 2010; Hepbasli, 2016) the significance of thermodynamics in aircraft engine design is strongly emphasized. The most prominent and commonly-recommended tool is exergy analysis, combining the first and second laws of thermodynamics for the design and optimization of an efficient aircraft engine. As a result, many studies on the exergy analysis of numerous aircraft engines have been presented in literature (Grönstedt, Irannezhad, Lei, Thulin, \& Lundbladh, 2013; Tai, See, \& Mares, 2014; Balli \& Hepbasli, 2014; Arntz, Atinault, \& Merlen, 2015; Colakoglu, Tanbay, Durmayaz, \& Sogut, 2016; Yucer, 2016; Şöhret, Ekici, Altuntaş, Hepbasli, \& Karakoç, 2016; Najjar \& AbuEisheh, 2016; Ekici, Sohret, Coban, Altuntas, \& Karakoc, 2016a; Yildirim, Altuntas, Mahir, \& Karakoc, 2017; Hayes, Lone, Whidborne, Camberos, \& Coetzee, 2017; Balli, 2017a; Coban, Colpan, \& Karakoc, 2017a; Yalcin, 2017; Balli, 2017b; Coban, Şöhret, Colpan, \& Karakoç, 2017; Mishra \& Sanjay, 2018).

*Corresponding author. E-mail: ysohret@gmail.com 
Mankind has encountered other environmental issues besides the depletion of energy sources. Environmental complications stemming from impassive energy utilization, such as global warming, climate change, ozone layer depletion, and so on, are also associated with the aforementioned concerns: sustainability, clean energy, and energy efficient design (Zecca \& Chiari, 2010; Winter, 2014; Chiari \& Zecca, 2011; Moghaddam, Ahlgren, Hulteberg, $\&$ Nordberg, 2015). Along with alternative fuels, renewables are introduced as possible solutions to combat these issues, and approaches and methods are also being developed for both environmental impact assessment and reduction of thermal systems utilizing conventional energy sources (Moghaddam et al., 2015; Bicer \& Dincer, 2016; Caiado, de Freitas Dias, Mattos, Quelhas, \& Leal Filho, 2017). Therefore, it is necessary to consider the environmental and ecological aspects of the systems in addition to performance augmentation. Within this context, the sustainability of energy consumption and the system gain importance. For this purpose, the first and second laws of thermodynamics, aided by sustainability assessment methodology, are commonly preferred in the literature available (Hepbasli, 2008; Romero \& Linares, 2014; Ekici, Altuntas, Açıkkalp, Sogut, \& Karako, 2016b; Kaya, Turan, Karakoç, \& Midilli, 2016; Ekici, Sohret, Coban, Altuntas, \& Karakoc, 2018).

Finite-time thermodynamics is a branch of thermodynamics which examines energy conversion systems with the constraints of finite time or finite size. A number of questions regarding energy conversion systems which cannot be explained through classical thermodynamics can be answered by finite-time thermodynamics. Studies by Nokivov (1954), Curzon and Ahlborn (1975) were concerned with the maximum power output limitation from a Carnot heat engine. Later, Bejan (1996) proposed a model to clarify the association between entropy generation within a power plant and the maximum power output (Chen, Wu, \& Sun, 1999; Yasunaga \& Ikegami, 2017). Further studies on finite-time thermodynamics present an evaluation of numerous systems and reveal the dark spots not covered by classical thermodynamics (Chen et al., 1999; Yasunaga \& Ikegami, 2017; Kaushik \& Kumar, 2000; Ahmadi, Sayyaadi, \& Hosseinzadeh,
2014; Özel, Açıkkalp, \& Yamık, 2015; Açıkkalp \& Yamik, 2015; Mousapour, Hajipour, Rashidi, \& Freidoonimehr, 2016; Zhou, Chen, Ding, \&, Sun , 2016; Ge, Chen, \& Sun, 2016; Acikkalp, 2017; Gonca, 2016; Ahmadi et al., 2018). Some of these later studies (Açıkkalp, 2017; Ahmadi et al., 2018) discuss the ecologic performance of evaluated systems. Within this framework, two parameters, namely the ecological function and ecological coefficient of performance, are defined and employed.

In the present study, the ecological performance and sustainability assessment of a turbojet engine under design conditions is introduced. In contrast to earlier studies, classical and finite-time thermodynamics approaches are used in an integrated way for the first time. For this purpose, the first and second laws of thermodynamics are employed to determine irreversibility within a turbojet engine as well as carry out a sustainability assessment based on exergy analysis. Additionally, the ecologic performance of the turbojet engine is examined from a perspective of finite-time thermodynamics.

\section{Turbojet engine and assumptions}

The genuine turbojet engine evaluated in the current study comprises an air inlet, air compressor, combustion chamber, gas turbine, exhaust nozzle components, and other accessories. The major characteristics of the engine are summarized in Table 1. The following calculations and analyses are carried out according to the station numbering illustrated in Figure 1 and the conjectures listed below:

- the engine operates under a steady state, steady conditions;

- heat leakage at the air compressor, the gas turbine and combustion chamber is neglected;

- the engine consumes conventional aviation fuel $(\mathrm{C} 11 \mathrm{H} 23)$ with a heating value of $44.169 \mathrm{MJ} / \mathrm{kg}$;

- the kinetic energy and exergy are neglected as well as the potential energy and exergy;

- the ambient temperature and pressure are considered to be $288.15 \mathrm{~K}$ and $101.325 \mathrm{kPa}$, respectively, according to sea level conditions of the International Standard Atmosphere (Torenbeek, 2013);

- the air is assumed to be composed of $78.12 \%$ nitrogen,

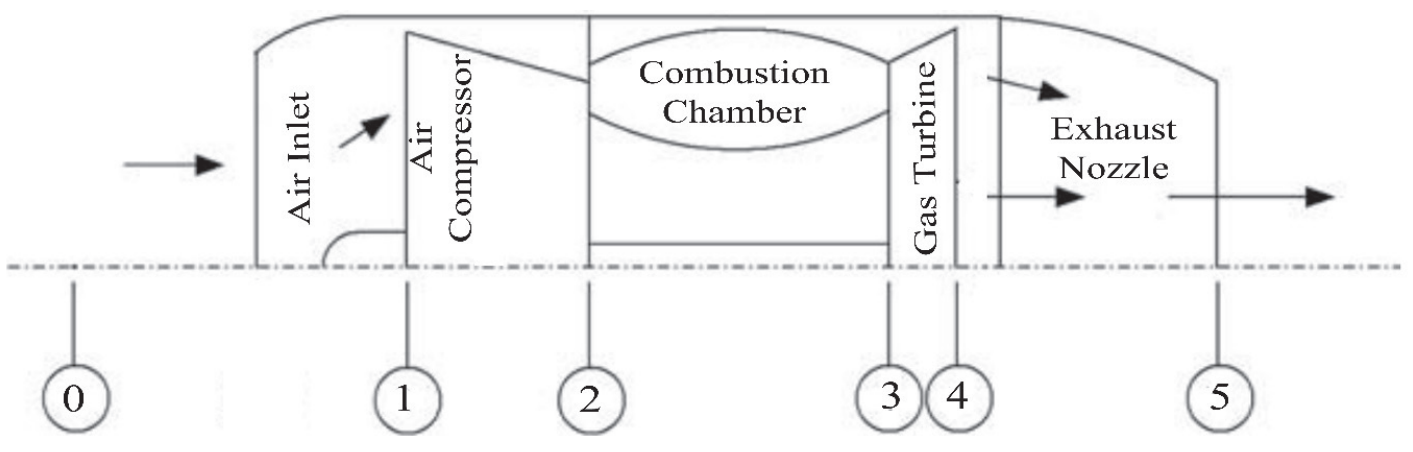

Figure 1. Schematic illustration of the turbojet engine (El-Sayed, 2008) 
Table 1. Major characteristics of the examined turbojet engine

\begin{tabular}{|l|c|c|}
\hline \multicolumn{1}{|c|}{ Parameter } & Unit & Value \\
\hline Inlet pressure ratio & - & 0.99 \\
\hline Compressor isentropic efficiency & $\%$ & 85.00 \\
\hline Compressor inlet Mach number & - & 0.54 \\
\hline Compressor pressure ratio & - & 6.93 \\
\hline Combustion efficiency & $\%$ & 99.99 \\
\hline Combustion chamber pressure loss & $\%$ & 3.00 \\
\hline Air to fuel ratio & - & 56.49 \\
\hline Turbine isentropic efficiency & $\%$ & 89.00 \\
\hline Turbine inlet temperature & $\mathrm{K}$ & 1095 \\
\hline Shaft mechanical efficiency & $\%$ & 99.00 \\
\hline Nozzle outlet velocity & $\mathrm{m} / \mathrm{s}$ & 568.80 \\
\hline Thrust & $\mathrm{kN}$ & 22.70 \\
\hline
\end{tabular}

$20.96 \%$ oxygen and $0.92 \%$ of other gases on a molar basis (Lemmon, Jacobsen, Penoncello, \& Friend, 2000).

\section{Exergy analysis}

Exergy analysis is a combined application of the first and second thermodynamic laws. The first and second law analyses of a steady-state system are conducted according to these governing equations (Kotas, Mayhew, \& Raichura, 1995; Dincer \& Cengel, 2001; Tsatsaronis, 2007):

$$
\begin{aligned}
& \sum \dot{m}_{\text {in }}-\sum \dot{m}_{\text {out }}=0 ; \\
& \dot{Q}-\dot{W}+\sum \dot{m}_{\text {in }}\left[h_{\text {in }}+e_{\text {in }}^{K N}+e_{\text {in }}^{P T}\right]- \\
& \sum \dot{m}_{\text {out }}\left[h_{\text {out }}+e_{\text {out }}^{K N}+e_{\text {out }}^{P T}\right]=0 ; \\
& \dot{E} x_{\text {in }}-\dot{E} x_{\text {ou }}-\dot{E} x_{D}-\dot{E} x_{L}=0 ;
\end{aligned}
$$

Exergy, denoted by Ex in Eq. 3, consists of physical, chemical, potential, and kinetic, exergy components (Kotas et al. 1995; Dincer \& Cengel 2001; Tsatsaronis, 2007):

$$
\dot{E} x=\dot{m}\left(e x^{P H}+e x^{C H}+e x^{K N}+e x^{P T}\right) \text {. }
$$

Specific physical ( $e x^{P H}$ ) and chemical ( $\left.e x^{C H}\right)$ exergies can be formulated as (Kotas et al., 1995; Dincer \& Cengel, 2001; Tsatsaronis, 2007):

$$
\begin{aligned}
& \operatorname{ex}_{i}^{P H}=c_{p, i}\left(T_{i}-T_{0}\right)-T_{0}\left(c_{p, i} \ln \frac{T_{i}}{T_{0}}-R \ln \frac{P_{i}}{P_{0}}\right) ; \\
& \overline{e x}_{i}^{C H}=-R T_{0} \ln \left(x_{i}\right) .
\end{aligned}
$$

Molar based chemical exergy of an ideal gas mixture and liquid fuel is found by (Kotas et al., 1995; Dincer \& Cengel, 2001; Tsatsaronis, 2007):

$$
\begin{aligned}
& \overline{e x}_{\text {mix }}^{C H}=\sum x_{i} \overline{e x}_{i}^{C H}+R T_{0} \sum x_{i} \ln \left(x_{i}\right) \\
& \overline{e x}_{\text {fuel }}^{C H}=L H V\left[1.0401+\left(0.0728(H / C)_{\text {fuel }}\right)\right] .
\end{aligned}
$$

The exergy balance given in Eq. (3) is written in compliance with the In-Out approach explained in Kotas et al. (1995), Dincer and Cengel (2001), Tsatsaronis (2007). Equations derived for each component of the examined engine are summarized in Table 2.

\section{Sustainability analysis}

The paper (Rosen, Dincer, \& Kanoglu, 2008) states that 'sustainable development requires not just that sustainable energy resources be used, but that the resources be used efficiently. Exergy methods are essential in improving efficiency, which allows society to maximize the benefits it derives from its resources while minimizing the negative impacts'. From this viewpoint, exergy and sustainable energy utilization are strongly linked. For this purpose, the exergy efficiency, waste exergy ratio, recoverable exergy rate, exergy destruction factor, exergetic environmental factor, and sustainability index are used as major sustainability indicators to evaluate sustainability with the aid of exergy (Balli, 2017b):

$$
\begin{aligned}
& \varepsilon=\frac{E x_{\text {out }}}{E x_{\text {in }}} ; \\
& r_{w e}=\frac{E x_{\text {waste }}}{E x_{\text {in }}} ;
\end{aligned}
$$

Table 2. Exergy balance statements for the turbojet engine and its components

\begin{tabular}{|l|c|c|c|}
\hline \multicolumn{1}{|c|}{ Component } & $\dot{\boldsymbol{E} \boldsymbol{x}_{\text {in }}}$ & $\dot{\boldsymbol{E} \boldsymbol{x}_{\text {out }}}$ & $\dot{E} \boldsymbol{x}_{\boldsymbol{D}}$ \\
\hline Air compressor & $\left(E_{2}-E_{1}\right)+E x_{1}$ & $E x_{2}$ & $\left(E_{2}-E_{1}\right)+E x_{1}-E x_{2}$ \\
\hline Combustion chamber & $E x_{2}+E x_{3}$ & $E x_{4}$ & $E x_{2}+E x_{3}-E x_{4}$ \\
\hline Gas turbine & $E x_{4}$ & $E x_{4}-\left(E_{4}-E_{5}\right)-E x_{5}$ \\
\hline Nozzle & $\left.E x_{5}\right)+E x_{5}$ & $E x_{5}-E x_{6}$ \\
\hline Turbojet Engine & $E x_{2}+E x_{3}$ & $E x_{6}$ & $E x_{2}+E x_{3}-E x_{\text {thrust }}$ \\
\hline
\end{tabular}




$$
\begin{aligned}
& r_{r e}=\frac{E x_{r e}}{E x_{i n}} ; \\
& f_{\text {exd }}=\frac{E x_{D}}{E x_{i n}} ; \\
& r_{e e f}=\frac{r_{w e}}{\varepsilon} ; \\
& \Theta=\frac{\varepsilon}{r_{w e}} .
\end{aligned}
$$

\section{Ecological performance analysis}

In the literature available, two main ecological performance indicators can be found. The first of these indicators, the ecological objective function, is defined as the difference between the useful work output rate of a system and the loss rate of availability. As such, it can be written in the manner of power and the loss rate of the availability (Angulo-Brown, 1991; Yan, 1993):

$$
E C O=\dot{W}-T_{0} \dot{S}_{g e n}
$$

The second ecological performance indicator, previously defined by Ust, Sahin, and Sogut (2005), is the ecological coefficient of performance, which is the ratio of the power output rate of the system to the loss rate of the availability for any thermal system:

$$
E C O P=\frac{\dot{W}}{T_{0} \dot{S}_{g e n}} .
$$

If the Gouy-Stodola relationship (Hepbasli, 2008) is borne in mind, and the power equivalence of the generated thrust of the turbojet engine is written as the power output, the ecological objective function and the ecological coefficient of performance can be written for a turbojet engine as follows:

$$
\begin{aligned}
& E C O_{T J E}=\dot{E} x_{\text {Thrust }}-\dot{E} x_{D, T J E} \\
& E C O P_{T J E}=\frac{\dot{E} x_{\text {Thrust }}}{\dot{E} x_{D, T J E}}
\end{aligned}
$$

\section{Results and discussion}

In the current paper, a turbojet engine is evaluated from the perspectives of ecological performance and sustainability. For this purpose, the first and second laws of thermodynamics are employed. For the first stage of the study, energy conversion and exergy balance statements are applied on the engine to reveal the exergy destruction rate of the turbojet and each component. Later, sustainability and ecological performance indicators are calculated according to the results obtained from the exergy analysis. The cycle data and thermodynamic quantities of the turbojet engine used in the calculations are provided in Table 3.

Figure 2 is plotted to demonstrate the energy and exergy flow rates of each engine station. If the energy and exergy rates of the fuel are excluded, the energy rate of the working fluid increases until it reaches that of the gas turbine inlet. Then the energy rate of the fluid drops as a result of the expansion process within the turbine component. The trend of the exergy rate of the working fluid is exactly the same as the variation of the energy rate. This indicates the consistency of the calculations as well as the validity of energy conversion and exergy balance regarding the data given in Table 3.

If exergy rates are examined on a component basis, the graph shown in Figure 3 is obtained. According to Figure 3, the exergy input rate of the air compressor, combustion chamber and gas turbine is $8458.338 \mathrm{~kW}, 33184.457 \mathrm{~kW}$, and $21659.023 \mathrm{~kW}$, respectively. The exergy destruction rate of the components for the air compressor, combustion chamber and gas turbine is calculated to be $1110.759 \mathrm{~kW}$, $11525.435 \mathrm{~kW}$, and $247.766 \mathrm{~kW}$, respectively. To reflect the exergy destruction rates of the engine components, the exergy efficiency variation of the components is illustrated in Figure 4. As evident from the plot, the exergy efficiency of the air compressor, combustion chamber and gas turbine is $86.86 \%, 65.26 \%$, and $97.19 \%$, respectively.

The results indicate that the combustion chamber is the most irreversible component associated with the highest exergy destruction. The combustion chamber is the component in which the chemical reaction occurs and yields irreversibility. Irreversibility linked to the chemical process is currently unavoidable with regards to the state of the art.

Table 3. Thermodynamic quantities of the turbojet engine stations

\begin{tabular}{|c|c|c|c|c|c|c|}
\hline Station \# & Fluid Type & Pressure $(\mathrm{kPa})$ & Temperature $(\mathrm{K})$ & $\begin{array}{c}\text { Mass Flow Rate } \\
(\mathrm{kg} / \mathrm{s})\end{array}$ & $\begin{array}{c}\text { Energy Rate* } \\
(\mathrm{kW})\end{array}$ & $\begin{array}{c}\text { Exergy Rate }^{*} \\
(\mathrm{~kW})\end{array}$ \\
\hline 1 & Air & 101.325 & 288.150 & 31.680 & 9162.801 & 0.000 \\
\hline 2 & Air & 702.182 & 536.649 & 31.680 & 17621.139 & 7347.578 \\
\hline 3 & Fuel & 101.325 & 288.150 & 0.560 & 24768.550 & 25836.878 \\
\hline 4 & Combustion Gas & 681.116 & 1095.000 & 32.240 & 42389.680 & 21659.022 \\
\hline 5 & Combustion Gas & 208.521 & 902.000 & 32.240 & 33803.458 & 12825.035 \\
\hline
\end{tabular}

Note: ${ }^{\star}$ Calculated value. 


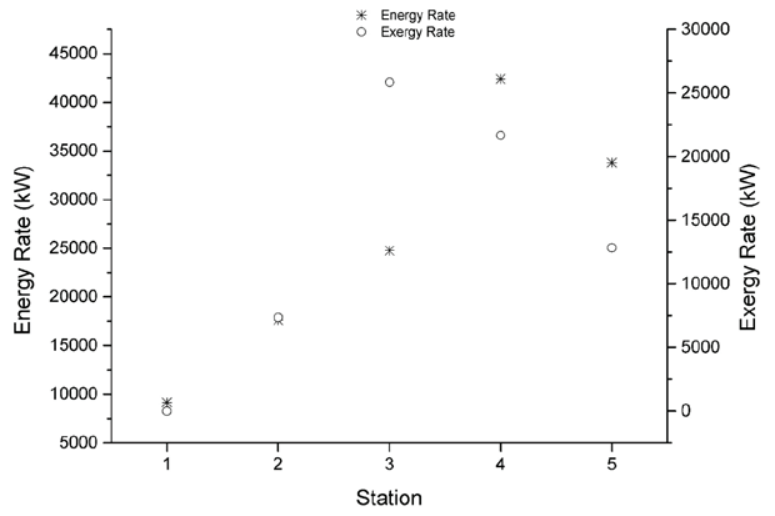

Figure 2. Energy and exergy rates of engine stations

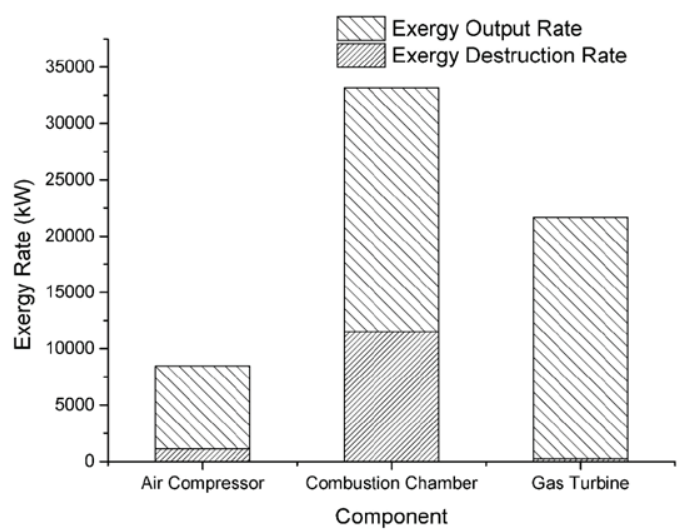

Figure 3. Decomposition of exergy input rate for each engine component

The indicators calculated for the sustainability assessment are collectively depicted in Figure 5. The exergy efficiency of the evaluated turbojet engine is found to be $50.13 \%$, whereas the waste exergy ratio and exergy destruction factor are determined to be 0.995 and 0.498 , respectively. According to the calculated exergy efficiency, approximately half of the exergy provided to the engine is converted into a useful output, thrust, while the rest of the input exergy rate is destroyed. The waste exergy ratio indicates the ratio of the wasted exergy rate, sum of exergy destruction rate and exergy rate of emitted exhaust gases, to the input exergy rate. A value of the waste exergy ratio close to 1.00 equals the equivalent wasted and input exergy rates of the turbojet engine. Since neither the destroyed nor exhaust gas can be recovered, the recoverable exergy rate for the turbojet engine is 0.00 . The value of the exergy destruction factor reveals the ratio of the destroyed exergy rate to the input exergy rate. On the other hand, it is clear that the ratio of the exergy rate of exhaust gas to the input exergy rate is 0.497 . In other words, the shares of the destroyed exergy rate and the exergy rate of the exhaust gases are approximately equal. The environmental effect factor clarifies the environmental impact of the engine in terms of wasted exergy. If decomposition of the waste exergy rate is borne in mind, the environmental effect is

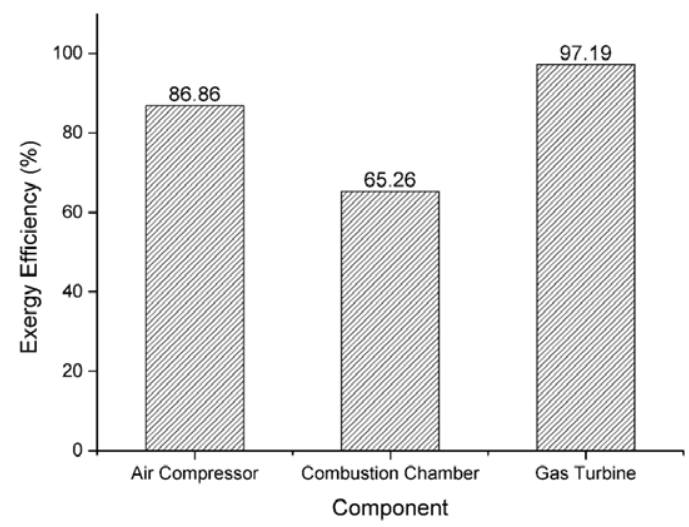

Figure 4. Exergy efficiencies of the engine components

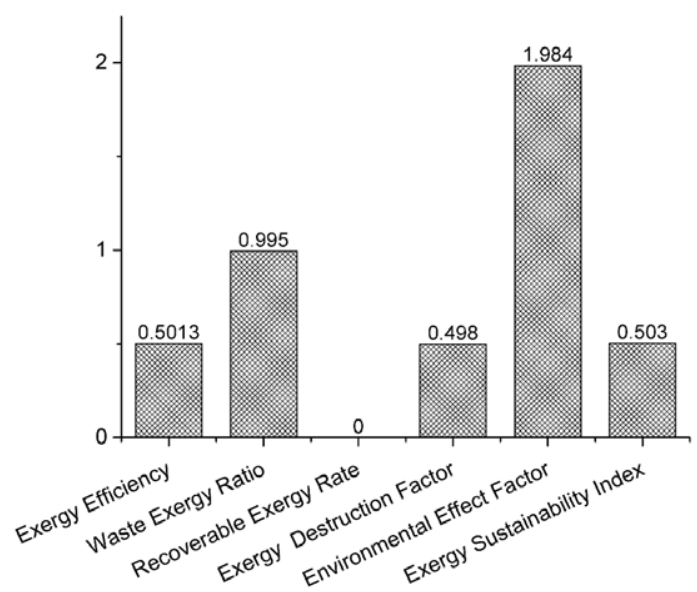

Figure 5. Sustainability indicators of the engine

associated with both the released exhaust gases and loss of availability. An increase in the environmental impact factor leads to a decrease of the sustainability index, as easily understood from mathematical formulations. Therefore, a reduction of exergy destruction and exergy rate of exhaust gases can yield a decrement in the environmental effect factor, as well as a rise in the sustainability index. As a result, a reduction in the rate of waste exergy plays a crucial role in augmenting the engine and achieving a more sustainable design.

The results of the ecological performance analysis are provided in Table 4. The ecological objective function helps to understand the relationship between the useful output of the system and exergy destruction. According to the results, the ecological objective function is calculated at $68.924 \mathrm{~kW}$. This value expresses the generated thrust, which is the useful output of a turbojet engine

Table 4. Ecological performance indicators of the turbojet engine

\begin{tabular}{|l|l|l|}
\hline \multicolumn{1}{|c|}{ Indicator } & \multicolumn{1}{c|}{ Unit } & \multicolumn{1}{c|}{ Value } \\
\hline Ecological objective function & $\mathrm{kW}$ & 68.924 \\
\hline $\begin{array}{l}\text { Ecological coefficient of } \\
\text { performance }\end{array}$ & - & 1.005 \\
\hline
\end{tabular}


and is greater than the exergy destruction rate within the turbojet engine. However, the ecological objective function is expected to be higher than zero as often as possible. Maximization of the ecological objective function favors a more efficient system design. From this point of view, the examined turbojet engine is relatively efficient. However, an ecological objective function which is close to zero indicates a need for improvements. The ecological coefficient of performance is another measure showing the relationship between thrust and exergy destruction rate, while the ecological objective function represents their ratio. The ecological coefficient of performance of an efficient thermal system is expected to be greater than zero. Even if it is less than zero, a requirement for improvement is obvious. In the current study, the ecological coefficient of performance obtained for the evaluated turbojet engine was 1.00. It could be stated that the turbojet engine under examination is neither efficient nor inefficient, since the values of the generated thrust and exergy destruction rate are approximately equal in virtue of neglecting the difference relative to the amount of thrust. In this sense, the author asserts a need for the improvement of the evaluated turbojet with respect to both the ecological objective function and the ecological coefficient of performance.

\section{Conclusions}

The ecological performance and sustainability assessment of a turbojet engine under design conditions are examined in the current paper. It was found during the analysis that the exergy efficiency, exergy sustainability index, ecological objective function and ecological coefficient of performance are $50.13 \%, 0.503, \mathrm{~F} 68.294 \mathrm{~kW}$, and 1.005 , respectively. Based on the obtained results, the following remarks can be made:

- A component based exergy analysis of the turbojet engine revealed that the combustion chamber is the main component inducing irreversibility and exergy destruction. To reduce exergy destruction in the combustion chamber design, improvement is not a perfect solution due to the nature of the chemical reaction. Therefore, novel and promising combustion technologies should be adopted for turbojet engines.

- Regarding high exergy destruction within the combustion chamber, the irreversibility rate of the overall turbojet engine increases, leading to a convergence of the thrust and exergy destruction rate.

- To improve the sustainability index and the ecological coefficient of performance, the exergy destruction rate of the turbojet engine should be minimized by increasing the thrust of the turbojet or keeping it constant.

In light of the observed results, the optimization of the evaluated turbojet engine taking into account the ecological performance indicators is planned for a future study.

\section{Acknowledgements}

The author is thankful to the reviewers for their constructive comments and contributions to improve the quality of the paper.

\section{References}

Açıkkalp, E. (2017). Ecologic and sustainable objective thermodynamic evaluation of molten carbonate fuel cell-supercritical $\mathrm{CO}_{2}$ Brayton cycle hybrid system. International Journal of Hydrogen Energy, 42(9), 6272-6280.

https://doi.org/10.1016/j.ijhydene.2016.12.110

Açıkkalp, E., \& Yamık, H. (2015). Modeling and optimization of maximum available work for irreversible gas power cycles with temperature dependent specific heat. Journal of NonEquilibrium Thermodynamics, 40(1), 25-39.

https://doi.org/10.1515/jnet-2014-0030

Ahmadi, M., Jokar, M., Ming, T., Feidt, M., Pourfayaz, F., \& Astaraei, F. (2018). Multi-objective performance optimization of irreversible molten carbonate fuel cell-Braysson heat engine and thermodynamic analysis with ecological objective approach. Energy, 144(1), 707-722. https://doi.org/10.1016/j.energy.2017.12.028

Ahmadi, M., Sayyaadi, H., \& Hosseinzadeh, H. (2014). Optimization of output power and thermal efficiency of solar-dish Stirling engine using finite time thermodynamic analysis. Heat Transfer-Asian Research, 44(4), 347-376. https://doi.org/10.1002/htj.21125

Alva, G., Lin, Y., \& Fang, G. (2018). An overview of thermal energy storage systems. Energy, 144(1), 341-378. https://doi.org/10.1016/j.energy.2017.12.037

Angulo-Brown, F. (1991). An ecological optimization criterion for finite-time heat engines. Journal of Applied Physics, 69, 7465-7469. https://doi.org/10.1063/1.347562

Arntz, A., Atinault, O., \& Merlen, A. (2015). Exergy-based formulation for aircraft aeropropulsive performance assessment: theoretical development. AIAA Journal, 53(6), 1627-1639. https://doi.org/10.2514/1.J053467

Balli, O., \& Hepbasli, A. (2014). Exergoeconomic, sustainability and environmental damage cost analyses of T56 turboprop engine. Energy, 64(1), 582-600.

https://doi.org/10.1016/j.energy.2013.09.066.

Balli, O. (2017a). Advanced exergy analyses of an aircraft turboprop engine (TPE). Energy, 124(1), 599-612. https://doi.org/10.1016/j.energy.2017.02.121

Balli, O. (2017b). Exergy modeling for evaluating sustainability level of a high by-pass turbofan engine used on commercial aircrafts. Applied Thermal Engineering, 123, 138-155. https://doi.org/10.1016/j.applthermaleng.2017.05.068

Bejan, A. (1996). Models of power plants that generate minimum entropy while operating at maximum power. American Journal of Physics, 64(1996), 1054-1059. https://doi.org/10.1119/1.18306

Bejan, A., \& Siems, D. (2001). The need for exergy analysis and thermodynamic optimization in aircraft development. Exergy, an International Journal, 1(1), 14-24.

https://doi.org/10.1016/S1164-0235(01)00005-X

Bicer, Y., \& Dincer, I. (2016). A comparative life cycle assessment of alternative aviation fuels. International Journal of Sustainable Aviation, 2(3), 181-202.

https://doi.org/10.1504/IJSA.2016.080240

Caiado, R., de Freitas Dias, R., Mattos, L., Quelhas, O., \& Leal Filho, W. (2017). Towards sustainable development through 
the perspective of eco-efficiency - A systematic literature review. Journal of Cleaner Production, 165(1), 890-904. https://doi.org/10.1016/j.jclepro.2017.07.166

Cash, D. (2017) Choices on the road to the clean energy future. Energy Research \& Social Science, 35, 224-226. https://doi.org/10.1016/j.erss.2017.10.035

Chen, L., Wu, C., \& Sun, F. (1999). Finite time thermodynamic optimization or entropy generation minimization of energy systems. Journal of Non-Equilibrium Thermodynamics, 24(4), 327-359. https://doi.org/10.1515/JNETDY.1999.020

Chiari, L., \& Zecca, A. (2011). Constraints of fossil fuels depletion on global warming projections. Energy Policy, 39(9), 5026-5034. https://doi.org/10.1016/j.enpol.2011.06.011

Coban, K., Colpan, C., \& Karakoc, T. H. (2017). Application of thermodynamic laws on a military helicopter engine. Energy, 140(2), 1427-1436. https://doi.org/10.1016/j.energy.2017.07.179

Coban, K., Şöhret, Y., Colpan, C., \& Karakoç, T. H. (2017). Exergetic and exergoeconomic assessment of a small-scale turbojet fuelled with biodiesel. Energy, 140(2), 1358-1367. https://doi.org/10.1016/j.energy.2017.05.096

Colakoglu, M., Tanbay, T., Durmayaz, A., \& Sogut, O. (2016). Effect of heat leakage on the performance of a twin-spool turbofan engine. International Journal of Exergy, 19(2), 173-198. https://doi.org/10.1504/IJEX.2016.075604

Curzon, F., \& Ahlborn, B. (1975). Efficiency of a Carnot engine at maximum power output. American Journal of Physics, 43(1975), 22-24. https://doi.org/10.1119/1.10023

Dincer, I., \& Acar, C. (2017). Smart energy systems for a sustainable future. Applied Energy, 194, 225-235. https://doi.org/10.1016/j.apenergy.2016.12.058

Dincer, I., \& Cengel, Y. (2001). Energy, entropy and exergy concepts and their roles in thermal engineering. Entropy, 3(3), 116-149. https://doi.org/10.3390/e3030116

Ekici, S., Sohret, Y., Coban, K., Altuntas, O., \& Karakoc, T. H. (2016a). Performance evaluation of an experimental turbojet engine. International Journal of Turbo \& Jet-Engines, 34(4), 365-375. https://doi.org/10.1515/tjj-2016-0016

Ekici, S., Altuntas, O., Açıkkalp, E., Sogut, M. Z., \& Karakoc, T. H. (2016b). Assessment of thermodynamic performance and exergetic sustainability of turboprop engine using mixture of kerosene and methanol. International Journal of Exergy, 19(3), 295-314. https://doi.org/10.1504/IJEX.2016.075666

Ekici, S., Sohret, Y., Coban, K., Altuntas, O., \& Karakoc, T. H. (2018). Sustainability metrics of a small scale turbojet engine. International Journal of Turbo \& Jet-Engines, 35(2), 113119. https://doi.org/10.1515/tjj-2016-0036

El-Sayed, A. (2008). Aircraft propulsion and gas turbine engines. Boca Raton, Florida, USA: CRC Press. https://doi.org/10.1201/9781420008777

Ge, Y., Chen, L., \& Sun, F. (2016). Progress in finite time thermodynamic studies for internal combustion engine cycles. Entropy, 18(4), 139. https://doi.org/10.3390/e18040139

Gonca, G. (2016). Performance analysis and optimization of irreversible Dual-Atkinson cycle engine (DACE) with heat transfer effects under maximum power and maximum power density conditions. Applied Mathematical Modelling, 40(1314), 6725-6736. https://doi.org/10.1016/j.apm.2016.02.010

Grönstedt, T., Irannezhad, M., Lei, X., Thulin, O., \& Lundbladh, A. (2013). First and second law analysis of future aircraft engines. Journal of Engineering for Gas Turbines and Power, 136(3). https://doi.org/10.1115/1.402572715/1.4025727

Hayes, D., Lone, M., Whidborne, J., Camberos, J., \& Coetzee, E. (2017). Adopting exergy analysis for use in aerospace. Progress in Aerospace Sciences, 93, 73-94.

https://doi.org/10.1016/j.paerosci.2017.07.004
Hepbasli, A. (2008). A key review on exergetic analysis and assessment of renewable energy resources for a sustainable future. Renewable and Sustainable Energy Reviews, 12(3), 593661. https://doi.org/10.1016/j.rser.2006.10.001

Hepbasli, A. (2016). Proposing an exergy management system standard for establishing exergetically green aviation. International Journal of Sustainable Aviation, 2(4), 271-283.

https://doi.org/10.1504/IJSA.2016.082196

International Energy Agency. (2017). World Energy Outlook. OECD/IEA.

Kaushik, S., \& Kumar, S. (2000). Finite time thermodynamic analysis of endoreversible Stirling heat engine with regenerative losses. Energy, 25(10), 989-1003. https://doi.org/10.1016/S0360-5442(00)00023-2

Kaya, N., Turan, Ö., Karakoç, T. H., \& Midilli, A. (2016). Parametric study of exergetic sustainability performances of a high altitude long endurance unmanned air vehicle using hydrogen fuel. International Journal of Hydrogen Energy, 41(19), 8323-8336. https://doi.org/10.1016/j.ijhydene.2015.09.007

Kotas, T., Mayhew, Y., \& Raichura, R. (1995). Nomenclature for exergy analysis, proceedings of the institution of mechanical engineers, Part A. Journal of Power and Energy, 209(4), 275-280. https://doi.org/10.1243/PIME_PROC_1995_209_006_01.

Lemmon, E., Jacobsen, R., Penoncello, S., \& Friend, D. (2000). Thermodynamic properties of air and mixtures of nitrogen, argon, and oxygen from 60 to $2000 \mathrm{~K}$ at pressures to $2000 \mathrm{MPa}$. Journal of Physical and Chemical Reference Data, 29, 331-385. https://doi.org/10.1063/1.1285884

Mishra, S., \& Sanjay. (2018). Energy and exergy analysis of air-film cooled gas turbine cycle: Effect of radiative heat transfer on blade coolant requirement. Applied Thermal Engineering, 129(25), 1403-1413. https://doi.org/10.1016/j.applthermaleng.2017.10.128

Moghaddam, E. A., Ahlgren, S., Hulteberg, C., \& Nordberg, Å. (2015). Energy balance and global warming potential of biogasbased fuels from a life cycle perspective. Fuel Processing Technology, 132, 74-82. https://doi.org/10.1016/j.fuproc.2014.12.014

Mousapour, A., Hajipour, A., Rashidi, M., \& Freidoonimehr, N. (2016). Performance evaluation of an irreversible Miller cycle comparing FTT (finite-time thermodynamics) analysis and ANN (artificial neural network) prediction. Energy, 94(1), 100-109. https://doi.org/10.1016/j.energy.2015.10.073

Najjar, Y., \& AbuEisheh, H. (2016). Exergy analysis and greening performance carpets for turbojet engines. Journal of Engineering Thermophysics, 25(2), 262-274. https://doi.org/10.1134/S1810232816020119

Özel, G., Açıkalp, E., \& Yamık, H. (2015). Methods used for evaluating irreversible Brayton cycle and comparing them. International Journal of Sustainable Aviation, 1(3), 288-298. https://doi.org/10.1504/IJSA.2015.070376

Riggins, D., Moorhouse, D., \& Camberos, J. (2010). Characterization of aerospace vehicle performance and mission analysis using thermodynamic availability. Journal of Aircraft, 47(3), 904-916. https://doi.org/10.2514/1.46420

Riggins, D., Taylor, T., \& Moorhouse, D. (2006). Methodology for performance analysis of aerospace vehicles using the laws of thermodynamics. Journal of Aircraft, 43(4), 953-963. https://doi.org/10.2514/1.16426

Romero, J. C., \& Linares, P. (2014). Exergy as a global energy sustainability indicator: A review of the state of the art. Renewable and Sustainable Energy Reviews, 33, 427-442. https://doi.org/10.1016/j.rser.2014.02.012

Rosen, M., Dincer, I., \& Kanoglu, M. (2008). Role of exergy in increasing efficiency and sustainability and reducing environmental impact. Energy Policy, 36(1), 128-137. https://doi.org/10.1016/j.enpol.2007.09.006 
Rosen, M., \& Etele, J. (2004). Aerospace systems and exergy analysis: applications and methodology development needs. International Journal of Exergy, 1(4), 411-425. https://doi.org/10.1504/IJEX.2004.005786

Şöhret, Y., Ekici, S., Altuntaş, Ö., Hepbasli, A., \& Karakoç, T. H. (2016). Exergy as a useful tool for the performance assessment of aircraft gas turbine engines: A key review. Progress in Aerospace Sciences, 83, 57-69.

https://doi.org/10.1016/j.paerosci.2016.03.001.

Tai, V., See, P., \& Mares, C. (2014). Optimisation of energy and exergy of turbofan engines using genetic algorithms. International Journal of Sustainable Aviation, 1(1), 25-42. https://doi.org/10.1504/IJSA.2014.062866

Torenbeek, E. (2013). Advanced aircraft design: Conceptual design, analysis, and optimization of subsonic civil airplanes. New York, USA: John Wiley and Sons. https://doi.org/10.1002/9781118568101

Tsatsaronis, G. (2013). Definitions and nomenclature in exergy analysis and exergoeconomics. Energy, 32(4), 249-253. https://doi.org/10.1016/j.energy.2006.07.002

Ust, Y., Sahin, B., \& Sogut, O. (2005). Performance analysis and optimization of an irreversible dual-cycle based on an ecological coefficient of performance criterion. Applied Energy, 82(1), 23-39. https://doi.org/10.1016/j.apenergy.2004.08.005

Winter, R. (2014). Innovation and the dynamics of global warming. Journal of Environmental Economics and Management, 68(1), 124-140. https://doi.org/10.1016/j.jeem.2014.01.005
Yalcin, E. (2017). Thrust performance evaluation of a turbofan engine based on exergetic approach and thrust management in aircraft. International Journal of Turbo \& Jet-Engines, 34(2), 177-186. https://doi.org/10.1515/tjj-2015-0065

Yan, Z. (1993). Comment on "An ecological optimization criterion for finite-time heat engines" [J. Appl. Phys. 69, 7465 (1991)]. Journal of Applied Physics, 73(7), 3583. https://doi.org/10.1063/1.354041

Yasunaga, T., \& Ikegami, Y. (2017). Application of finite-time thermodynamics for evaluation method of heat engines. Energy Procedia, 129, 995-1001. https://doi.org/10.1016/j.egypro.2017.09.224

Yildirim, E., Altuntas, O., Mahir, N., \& Karakoc, T. H. (2017). Energy, exergy analysis, and sustainability assessment of different engine powers for helicopter engines. International Journal of Green Energy, 14(13), 1093-1099. https://doi.org/10.1080/15435075.2017.1358626.

Yucer, C. (2016). Thermodynamic analysis of the part load performance for a small scale gas turbine jet engine by using exergy analysis method. Energy, 111, 251-259. https://doi.org/10.1016/j.energy.2016.05.108

Zecca, A., \& Chiari, L. (2010). Fossil-fuel constraints on global warming. Energy Policy, 38(1), 1-3. https://doi.org/10.1016/j.enpol.2009.06.068.

Zhou, J., Chen, L., Ding, Z., \& Sun, F. (2016). Analysis and optimization with ecological objective function of irreversible single resonance energy selective electron heat engines. Energy, 111, 306-312. https://doi.org/10.1016/j.energy.2016.05.111 